Please refer to and cite the published version: Matheson, C. M. and Tinsley, R. 2016. The carnivalesque and event evolution: a study of the Beltane Fire Festival. Leisure Studies. 16(1), pp.1-27. http:// dx.doi.org/10.1080/02614367.2014.962591

\title{
The carnivalesque and event evolution: a study of the Beltane Fire Festival
}

Catherine M. Matheson ${ }^{\mathrm{a}}$ and Ross Tinsley ${ }^{\mathrm{b} *}$

${ }^{a}$ Division of Business, Enterprise and Management, School of Arts, Social Sciences and Management, Queen Margaret University, Edinburgh, Queen Margaret University Drive, Musselburgh, East Lothian EH21 6UU, UK; ${ }^{b}$ HTMi, Hotel and Tourism Management Institute Switzerland, 6174 Soerenberg, Kanton Luzern, Switzerland

(Received 18 November 2012; accepted 21 August 2014)

This paper centres on the Beltane Fire Festival (BFF) in Edinburgh, Scotland. The objectives are to: first, identify the stages of the festival's evolution and their respective characteristics; second, distinguish features corresponding to the carnivalesque; and, finally, examine the changes in event evolution, particularly regulatory interventions, and their effect. A qualitative approach comprising interviews with internal and external festival stakeholders was utilised. It is argued that there are three stages in the festival's evolution: revival and early development; development and regulation; and, maturation. The characteristics of these evolutionary stages are identified. As the festival has developed and been subject to increasing regulation, features of the carnivalesque have been reduced.

Keywords: carnivalesque; festival; regulation; evolution Introduction

\section{Introduction}

This paper examines the evolution of the Beltane Fire Festival (BFF) in Edinburgh, Scotland and the carnivalesque features within the festival. Carnival and carnivalesque qualities are linked to Bakhtin's (1984a, 1984b) seminal work on medieval carnival and festivities (Webb, 2005). Carnival signalled a temporary suspension of regulatory forces and an opportunity for participants to transgress societal conventions (Bakhtin, 1984a, 1984b). Bakhtin's (1984a, 1984b) concepts have been applied to, for example, events (Anderton, 2008, 2011; Harcup, 2000; Islam, Zyphur, \& Boje, 2008; Kates \& Belk, 2001; Ravenscroft \& Matteucci, 2003), music and dance cultures (Hanlon, 2004; Presdee, 2000; Vitos, 2010) and these existing studies often concentrate on the following. First, contemporary studies have applied Bakhtin's (1984a, 1984b) theorisation to events and identified those features corresponding to the carnivalesque (Gilmore, 1995; Kates, 2003; Kates \& Belk, 2001; Ravenscroft \& Matteucci, 2003). Second, studies have tended to apply these conceptualisations to major events (Anderton, 2008; Islam et al., 2008; Kates, 2003; Kates \& Belk, 2001), and there is less work on small-scale events (Harcup, 2000). This paper builds on existing work by identifying features of the carnivalesque within the context of the evolution of a small-scale festival, the BFF. Event evolution studies

*Corresponding author. Email: rtinsley@ @ htmi.ch @ 2014 Taylor \& Francis 
are wide-ranging (Higham \& Ritchie, 2001; Lade \& Jackson, 2004; Quinn, 2006; Sofield, Mei, \& Li, 1998; Sofield \& Sivan, 2003) and the identification of life cycle stages (Beverland, Hoffman, \& Rasmussen, 2001; Richards \& Ryan, 2004) is a common theme. Broadly, events evolve through stages of birth, growth, maturity and thereafter, decline or revival and, as such, reflect models drawing upon Levitt's product life cycle (1965) and more lately, Butler's (1980) adaptation to tourism destinations. The dynamic nature of festival evolution, as well as key factors of success and failure is a common narrative in these studies.

Beltane festivals historically occurred throughout Europe (Frazer, 1922), but dwindled with the onset of modernity and, by the early twentieth century, the Edinburgh Beltane festival had come to a close (Beltane Fire Society [BFS], 2013). In the late 1980s, the BFF was revived by a group of cultural community stakeholders. The festival marks the passage of the seasons, as did its predecessor, and contains spiritual overtones from its Celtic and pagan history. There are also unorthodox performance aspects. Initially, the festival was characterised by limited control and regulation; however, the festival has since sought to comply with legal and regulatory measures. Festivals, in common with other leisure activities, have been subject to increasing risk management measures (Silvers, 2007; Tarlow, 2002). Thus, the evolution of the BFF illustrates the effects of these regulatory changes and interventions in the wider festival and leisure landscape.

This paper identifies features of the carnivalesque (Bakhtin, 1984a, 1984b) within the contemporary BFF and how these have altered as the festival evolved, particularly given regulatory interventions. The objectives are to: first, identify the stages of the festival's evolution and their respective characteristics; second, distinguish features corresponding to the carnivalesque; and finally, examine the changes in event evolution, particularly regulatory interventions and their effect. The study has both a theoretical and practical purpose. Theoretically, existing work has identified life cycle stages (Beverland et al., 2001; Richards \& Ryan, 2004) and features of the carnivalesque in events (Gilmore, 1995; Kates, 2003; Kates \& Belk, 2001; Ravenscroft \& Matteucci, 2003), but there is little bringing these aspects together. Examining an event through an evolutionary lens provides an opportunity to acquire an insight into the factors shaping the event life cycle and their influence on the carnivalesque. Further, while Bakhtin (1984a) suggested that there was a temporary suspension of regulatory forces during carnival, the contemporary situation is instead characterised by substantial regulatory interventions, which thereby provides an occasion to illustrate the applicability, or otherwise, of Bakhtin's (1984a, 1984b) thesis to the contemporary situation. Practically, this paper highlights the stages in the BFF's evolution and the influence of external and internal factors, which can thereby inform event stakeholders. There is a need to understand how events have developed and the factors shaping event evolution (Getz, 2008), as this can shed light on issues contributing to event sustainability. 


\section{Theorising the carnivalesque and event evolution}

\section{Defining the evolving carnivalesque}

Carnival could be the oldest pagan festival, but its precise beginnings are difficult to specify (Gilmore, 1998). Carnival means 'farewell to the flesh' (Nurse, 1999, p. 664) or 'to take away or remove fat or meat' (Gilmore, 1998, p. 9). Associations between carnival and Lent are well established (Gilmore, 1995; Nurse, 1999).

Carnival can signify a day of excess prior to Lent (Gilmore, 1998) and denotes ' ... a period of celebration of the body, of physical abandon, where licentiousness, hedonism and sexual excess are expressed in music, dancing, masquerading and feasting' (Nurse, 1999, p. 664).

Bakhtin (1984a) examined medieval carnival and feasts functioning outwith official life and defined carnival as:

... not a spectacle seen by the people; they live in it, and everyone participates because its very idea embraces all the people. While carnival lasts, there is no other life outside it. During carnival time life is subject only to its laws, that is, the laws of its own freedom. (Bakhtin, 1984a, p. 7)

The carnivalesque was a broader concept which could be interpreted '... not only as carnival per se in its limited form but also as the varied popular-festive life of the Middle Ages and the Renaissance' (Bakhtin, 1984a, p. 218). Bakhtin (1984a, 1984b) paints a picture characterised by a temporary liberation from social conventions, hierarchal inversion and a 'second life' for participants. The excesses that Bakhtin (1984a, 1984b) described have not continued entirely within the carnivalesque of contemporary society (Connor \& Farrar, 2004) because state intervention, regulatory influences and other actors have diluted it.

While the state has long impinged on the carnivalesque through restrictions (Bakhtin, 1984a), marginalisation and repression (Rojek, 1995; Stallybrass \& White, 1986), other curbing forces were the Church, middle classes and modernising influences (Presdee, 2000). The middle classes appropriated popular festive forms to create profit and appropriate entertainment (Presdee, 2000). Rojek (1995) argued that carnivalesque qualities were marginalised and pushed to society's fringes by referring to the 'moral cleansing' campaigns of the seventeenth century, rational recreation programmes and peripheralisation of fairs in the nineteenth century, as well as similar practices of a peripheralisation of leisure practices in the USA to illustrate his contention. Stallybrass and White (1986) similarly note attacks on European manifestations of carnival and popular festivity from the seventeenth to the twentieth century through legislative and control measures.

Repression of the carnivalesque (Rojek, 1995; Shields, 1991; Stallybrass \& White, 1986), particularly in a modern context, occurred because it was ' ... seen politically as sites of obstruction to the encroaching powers of capital and the state' (Rojek, 1995, pp. 85-86). Characteristics of excess, inversion of social conventions and general disorder presented a 
threat to the social order. Disorders were not isolated incidents because '... there are many moments in the history of carnival where behaviour has broken free of festive restraint and licence and enacted, within the framework of the celebration, a real and violent revolution or rebellion' (Presdee, 2000 p. 42). Examples range from the May Day celebrations (1571), anti-Salvation Army demonstrations (1834) and the Notting Hill carnival (1976) (Presdee, 2000) to historical Halloween events (Rogers, 2002). Threats to order could result in radical repression, for example, carnival was banned by both Spanish dictators, Primo de Rivera and Franco, because of this issue about order (Gilmore, 1995). The church and secular elite also often perceived carnival as a potential or real place of disorder requiring continual surveillance (Scott, 1990). Although the carnivalesque was broken up because of marginalisation, fragmentation, repression and sublimation processes, it did not vanish from the social and cultural landscape; rather, it reappeared in a different format (Stallybrass \& White, 1986).

More recently within the context of festivals, the carnivalesque has been subject to external pressures, namely commodification, regulation and professionalisation.

Commercialisation pressures (Anderton, 2008, 2011; Finkel, 2010) bring ownership and identity issues. Kates and Belk's (2001) investigation of the Lesbian and Gay Pride Day indicates that although consumer experiences of commercialisation were contested, participants could use the space to negotiate their identity. Recognition of the value of festivals to economic and tourism development has also contributed to their commodification. For example, Langman (2003a) highlights that the Rio carnival has become a commodity, namely a tourist attraction, but has maintained its individual identity. Commodification is a perennial issue regarding festivity. Since Greenwood's (1977) examination of commodification and a public ritual, commodification effects on festivity have been scrutinised (Boissevain, 1996; Matheson, 2008; Whitford, 2008), regarding the experience and perceived authenticity.

Event regulation and professionalisation also impinge on the carnivalesque. Although Bakhtin (1984a) suggested that participants embraced the experience, in contrast, Anderton (2008) argues the carnivalesque experience may not be what participants seek. The reason being a change in consumer attitudes, as with greater festival professionalisation, there is more emphasis on security, safety and customer service (Anderton, 2008). This is not to suggest that carnivalesque experiences are rejected entirely, rather that, in certain milieus, they have been replaced by other discourses.

There is evidence to indicate an increasing regulation of events under the auspices of risk management, particularly health and safety (Silvers, 2007; Tarlow, 2002). Regulatory interventions are not a new phenomenon, as illustrated by Stallybrass and White (1986). It may be suggested that the standardisation of contemporary regulatory practices bears a resemblance to Ritzer's (2011) rationalisation thesis with its emphasis on control, efficiency, predictability and calculability. These regulatory interventions ensure that the event experience is controlled, regulated and standardised. Certain leisure practices, such as raves and outdoor gatherings were able, albeit temporarily, to evade such rationalisation, but have since become regulated. For example, the UK Government's Criminal Justice and Public Order Act (1994) had repercussions for underground 
activities, which have since moved into the mainstream club scene (Critcher, 2000; Partridge, 2006) and had implications for small-scale events too (Wiles, 1996). Despite the many changes affecting the carnivalesque, it continues in fragmented form (Stallybrass \& White, 1986), within a multiplicity of milieus.

This can be illustrated by the application of Bakthin's work to a variety of contexts. Santino (2011, p. 67) argued that 'the concept of carnivalesque is correctly restricted to Bakhtin's specifics, but it has become widely used to refer to festivity generally'. Yet the theorisation (Bakhtin, 1984a, 1984b) has gone beyond an analysis of carnival and festivity (Anderton, 2008; Islam et al., 2008; Kates, 2003; Ravenscroft \& Gilchrist, 2009; Ravenscroft \& Matteucci, 2003) into wider realms, such as cultural criminology (Presdee, 2000) and cultural and leisure practices (Philips, 1998; Shields, 1990; Webb, 2005). Thus, Bakhtinian concepts apply to festivities and practices, providing space for the fragmented carnivalesque. Langman's (2003a, 2008) work on body modification illustrates this because these practices signify transgression and the inversion of social norms, both of which are key features of Bakhtin's (1984a) theory. In a similar vein, Presdee (2000) highlights that rave culture not only retains features of the carnivalesque, but also encapsulates key

issues pertaining to the evolution of the carnivalesque, namely its fragmentation and repression via regulatory influences. Arguing that 'the fragmentation of 'rave' is like the fragmentation of carnival', Presdee (2000, p. 120), suggests that although the original rave scene was curtailed because of legislative responses, there are still carnivalesque occasions, such as the commodified Ibiza club experience where clubbers can misbehave or free party gatherings. Presdee (2000) goes further suggesting that the threshold occupied by the carnvialesque is broad with one end of the spectrum containing carnival elements in popular culture, a middle ground existing in more contested legal regions such as the aforementioned raves; and at the other end of the spectrum, the carnival of crime such as joyriding and stock market manipulation, which all involve edgework and with a similarly resultant thrill and rush of adrenaline.

Despite the seductive aspects of the theorisation (Bakhtin, 1984a, 1984b), there are criticisms. The carnivalesque could be about the affirmation of social order and the existing state of play, as alluded to by Bakhtin (1984a), and a release mechanism (Gilmore, 1998; Kates \& Belk, 2001; Ravenscroft \& Matteucci, 2003) and safety valve to protect and maintain the existing social order. The interpretation of carnival as a subterfuge for preserving existing hierarchies and order has been noted. Ravenscroft and Gilchrist (2009 p. 37) argue that: 'carnival did not challenge the power and presence of Church or state but upheld the political order, despite the prospect that such revelry might foster a utopian radicalism'. In contrast, Scott (1990 p. 178) disputes the supposition that carnival is a social control device sanctioned by the elite:

It is surely not accurate to proceed as if carnival were set up exclusively by dominant groups to allow subordinate groups to play at rebellion lest they resort to the real thing ...It would be just as plausible to view carnival as an ambiguous political victory wrested from elites by subordinate groups. 
He goes on to argue that if the safety-valve theory guided the actions of the elite, then one would anticipate carnival being encouraged, particularly in periods of social tension; however, the reverse is the case. He argues that both the church and secular elite have tended to perceive carnival as a potential or real place of disorder requiring continual surveillance (Scott, 1990), as exemplified earlier, given its repression (Rojek, 1995; Shields, 1991; Stallybrass \& White, 1986). An alternative perspective to this dichotomy is provided by Presdee (2000, p. 42), who argues that 'to say that carnival is either a tool for oppression or a vehicle for potentially subversive expression is too simplistic, since it is both of these things, each articulated through a series of symbolic and cultural actions'. Thus, the carnivalesque can simultaneously be a mechanism for repression and subversion. At this juncture, it is necessary to delineate key features of the carnivalesque and their contemporary application.

\section{Features of the carnivalesque}

The carnivalesque possesses distinctive features, such as transgression; inversion and subversion of roles and hierarchy; grotesque realism; hierarchical suspension; equality of participation; regeneration and renewal of the self; humour, often scatological; and a second life for its participants (Bakthin, 1984a, 1984b). The following elaboration of carnivalesque features has been distilled to the suspension and subversion of hierarchical structures; regulatory suspension and transgression; equality of participation; and grotesque realism.

First, carnival was a period when hierarchal structures were not only suspended and subverted, but social relations were liberated by the displacement of conventional barriers. Bakhtin (1984a, p. 10) suggested that ' ... carnival celebrated temporary liberation from the prevailing truth and from the established order; it marked the suspension of all hierarchical rank, privileges, norms, and prohibitions'. He goes on to argue that '... all were considered equal during carnival ... a special form of free and familiar contact reigned among people who were usually divided by the barriers of caste, property, profession and age' (Bakhtin, 1984a, p. 10). Temporary hierarchical reversal (Bakhtin, 1984a) can be illustrated by the Rio carnival which was a period of 'ironic inversions and reversals of normal hierarchies: the poor can experience luxury as they dress in fantasised splendour and, for a moment, be dukes and ladies, or rogues and villains. Men dress as women, women as men' (Langman, 2003a, p. 230). Participants chose their carnival identity (Langman, 2003a), while playfully dismantling hierarchical conventions. Hierarchical structures could also be subverted by mocking those in the upper echelons of society. Certainly, religious and political figures can be subject to mockery, ridicule and symbolic violence during the carnivalesque (Kates, 2003; Lindahl, 1996; Wiles, 1996).

This notion of carnival as non-hierarchical and a means to challenge the social order has been criticised. Lindahl (1996, p. 63) rejected Bakhtin's (1984a) assertion that the carnivalesque was non-hierarchical because at the Cajun Country Mardi Gras, it ' ... is absolutely hierarchical in structure'. During carnival, there may be a reversal of power structures, but it occurs in a milieu of inequality. There is a hierarchy of captain, lieutenants and riders and codes of conduct are assiduously adhered to (Lindahl, 1996), 
thereby denoting the hierarchies of the group from those that are the most powerful and otherwise. Similarly, Ravenscroft and Matteucci (2003) noted that festivity could preserve social order and gender structures. Within a patriarchal Spanish community, the annual San Fermin fiesta generally forbids women from taking part in the encierro (the bull run); however, they participate if they are dressed as men (Ravenscroft \& Matteucci, 2003). Issues of inequality and preservation of order are also highlighted in the Rio Carnival. Langman (2003a) argued that Carnival reinforced the hegemony of political and social structures; the rationale being that it does not act as agent of change because impoverished participants look to the next carnival rather than greater social change.

Second, there can be a suspension of regulation and accompanying transgression from social norms. Regulatory adjournment occurred because 'the laws, prohibitions, and restrictions that determine the structure and order of ordinary, that is noncarnival, life are suspended during carnival' (Bakhtin 1984b, pp. 122-123). The consequence of regulatory suspension was licentiousness and transgression from social norms. Carnival was about '... times of indulgence in wine, song, dance, and sex' (Langman, 2003b, p. 68). Thus, the carnivalesque can be a period when what is customarily restricted and prohibited becomes acceptable (Langman, 2008), whether that is riotous behaviour and public indecency during Andalusian carnival (Gilmore, 1995) or the sense of exuberance, licentiousness and freedom that characterises the Sydney gay and lesbian Mardi Gras (Kates, 2003).

This suspension of regulation provides a liberating experience for participants as social mores, conventions and regulatory devices are deferred; however, there are limitations. Rogers (2002) noted that in the early twentieth century, individuals incurring the anger of the community were penalised during Halloween, with little hope of protection or justice from customary sources. Hence, the suspension of

regulation can be a means to include and exclude community members. Furthermore, in the modern age, leisure activities are subject to regulation, primarily risk management related (Silvers, 2007; Tarlow, 2002), although social and political concerns have also been influential in regulatory change (Rojek, 1995). Undoubtedly, festivities are subject to regulatory control, such as the Lewes Bonfire Festival (Wiles, 1996), the Burning Man event (Chen, 2009) and Halloween celebrations (Rogers, 2002), but this needs to be seen in a wider context. These are not isolated scenarios, but are symptomatic of an age characterised by regulation and control under the guise of risk management. Thus, although Bakhtin (1984a) highlighted the lack of regulation within the carnival, festivals with carnivalesque qualities are subject to significant regulation and control.

Third, during the 'second life', the distinction between performers and spectators was abandoned (1984b). Bakhtin (1984a ,1984b, p. 122) argued that:

Carnival is a pageant without footlights and without a division between performers and spectators. In carnival everyone is an active participant ... they live a carnivalistic life ... it is to some extent 'life turned inside out', 'the reverse side of the world'.

Analyses of contemporary festivities illustrate that divisions between performers and spectators can be broken down and blurred (Harcup, 2000; Islam et al., 2008; Langman, 
2003a) or vociferously rejected (Kozinets, 2002). Performers can become spectators and vice versa at the St Valentine's Fair (Harcup, 2000) and Rio carnival (Langman, (2003a). In some milieus, there is a rigid demarcation between performer and spectator, to the extent that there can be substantive pressure for festive consumers to conform to specific roles. At the Burning Man festival, there is an expectation that everyone is a participant and spectators are actively discouraged (Kozinets, 2002). While this conforms to carnival tenets (Bakthin, 1984b), it also highlights the constraints of an expected rather than natural spontaneity. Nevertheless, it can afford its participants a temporary 'second life' (Wiles, 1996).

Fourth, carnival was characterised by laughter and grotesque realism. The principle of the latter was ' ... degradation, that is, the lowering of all that is high, spiritual, ideal, abstract; it is a transfer to the material level, to the sphere of earth and body in their indissoluble unity' (Bakhtin, 1984a, pp. 19-20). At contemporary festivities, there are representations of the grotesque body (Connor \& Farrar, 2004), bodily functions (Hanlon, 2004; Islam et al., 2008) and overt displays of sexuality and fertility (Islam et al., 2008). Similarly, representations of grotesque realism can be identified within the club culture scene, for example, in the psytrance club scene where there can be bizarre and eccentric forms of dress (O'Grady, 2012). Hanlon (2004) elaborates on shock music and the celebration of the grotesque body and bodily functions. These representations of bodily functions may be considered vulgar, but within the second life, bodily functions become part of the performance (Hanlon, 2004). Grotesque humour can be used for political criticism, for example, during the New Orleans Mardi Gras, sexual metaphors were deployed to mock political events (Islam et al., 2008). Festival displays and costumes can embody the grotesque and require skill (Kates, 2003) and 'cultural capital' (Bourdieu, 1984) in unpicking visual metaphors. For example, at Sydney's Gay and Lesbian Mardi Gras ‘... celebrants were treated to the display of several marchers wearing large red costumes uncannily resembling women's tampons called "the Bloody Marys"” (Kates, 2003, p. 10). This related to the government's goods and services tax and its application to toiletries, including tampons, which led to criticism by women's groups. Gay men also wore the costumes to express their criticism. Kates (2003) argued that for onlookers to understand the display, they would need to know that the tax was subject to criticism and that Mary was an informal term used by gay men for themselves. Finally, to evaluate the interplay between carnivalesque and festival evolution, it is necessary to focus on the latter.

\section{Festival evolution}

The product life cycle (Levitt, 1965) has already been adapted in tourism destination contexts, particularly resorts (Butler, 1980) and it can also be profitable as a framework for understanding event evolution. Xie and Lane (2006) have successfully used the model in the context of an aboriginal arts performance with adjustments made to reflect issues of authenticity, commodification for tourists, revitalisation and management input. The study notes a five-stage process of change with organic growth transforming to management as the dominant strategy for continued development. Their study acknowledges the limitations of the linear life-cycle model, noting that tourism is often a dynamic and complex system with a multitude of development layers at play at any one time. 
According to Quinn (2006), the life-cycle model may not always succeed in explaining performing arts and festival development, but can nevertheless be useful in explaining and understanding change in such contexts.

Beverland et al. (2001) adapted the aforementioned organisational and tourist area lifecycle models to an events context, in this case, events in the Australian wine sector. In their event life-cycle model, six stages are identified, with Butler's (1980) five stages in parenthesis: (1) conception; (2) launch [involvement/exploration]; (3) growth [development]; (4) consolidation [consolidation]; [stagnation]; (5) decline; and (6) revival [decline/rejuvenation]. Rather than the stages being cumulative and conjunctive, they found them to be punctuated by crisis, the overcoming of which took the wine events to the next stage. Addressing criticisms of the linear nature of such models and building on the work of Getz (1993) and Higham and Ritchie's (2001) subsequent adaption, Richards and Ryan (2004) suggest three axes: informal/grassroots resource base; organisational age; and organised public and private sector involvement. This still allows for recognition of a continuum from informality to professionalisation yet also permits professionalisation and public/private sector involvement at different stages. Thus, allowing for dynamic elements within the linear process.

Nevertheless, the deployment of the product life cycle to the festival context is not without its limitations. Xie and Lane (2006) suggest that there are issues of applicability to one-off, temporary events and, moreover, that the impact of external forces may result in the nature of the curve not always being followed, for example, legislative changes and natural disasters. Additionally, Getz (2000) questions how 'growth' and 'success' can be measured. In using the life cycle, there needs to be some measures (e.g. demand, revenue, attendance). However, if the purpose of the event is, for example, community pride, then this requires the development of alternative measures (Getz, 2000). Nevertheless, as a management tool to monitor change, the concept can assist planners to understand and explain changes, especially in the latter stages of growth, where the management of the festival is critical to ensure continued sustainability (Xie \& Lane, 2006). This raises the issue of stagnation and rejuvenation, and the measures which need to be implemented,

particularly in the maturation phase in order to avoid event decline. Festivals can undergo a multitude of internal and external challenges and crises, such as leadership issues, competition and funding. The life-cycle model provides an avenue to chart these problems and the adaptive strategies which have been implemented to ensure festival sustainability (Getz, 2002). Getz and Andersson (2008) argue that, ultimately, failure/ success is most likely to be attributable to managerial/organisational success. They argue 'a festival that is able to retain its market popularity, political support, and resources over a long period of time, possibly "rejuvenating" itself along the way, can be considered to have become "sustainable"" (Getz \& Andersson, 2008, p. 5).

In the context of festival evolution, studies have focussed on the inherent dynamics as well as key factors in success and failure. Richards and Ryan's (2004) study of a traditional Maori performing arts festival found tensions occurring as grassroots support, government policy and commercial sponsorship converged. However, these challenges 
can be seen as 'forces of creative destruction' (Richards \& Ryan, 2004, p. 115), resulting in problems becoming opportunities. They argue 'cultural festivals mirror many different dynamics and are places of discourse between different paradigms of traditional and evolving culture, between minority and majority groupings, between a need for independence and a dependency, usually on public authorities that might in other circumstances be seen as part of the majority-dominated structures' (Richards \& Ryan, 2004 , p. 115). The festival allows for a sense of identity to be confirmed, yet also challenged by the need for creativity and experimentation. Within this, key figures and personalities were found to play a vital role. In a study of an 800-year-old festival, Sofield et al. (1998) also emphasised the benefits of researching given situations over time, rather than 'snapshots' to seek out a holistic understanding of the interweaving dynamics of economic, sociocultural and political forces. Such an approach 'reveals the interplay between the long-term continuities and shorter-term cycles' (Sofield et al., 1998, p. 288).

Building on an earlier assertion that little research has been undertaken on festival failure and life cycles (Getz, 2000), Getz's (2002) study on festival crisis and failure identified a number of factors at play: dependency on one source of revenue; lacking private sector sponsorship; insufficient promotion; poor strategic planning; and the weather. He also suggested that failure was widespread, noting crucial differences from other non-festival related organisations in their tendency to be volunteerled, not-for-profit and externally dependent for various resources. However, Getz (2000) also argues that where events are less tied to commercial and profit-related goals, they are less likely to be affected by competition and age. Conversely, Lade and Jackson (2004) examined key success factors of regional festivals. These included a unique and creative festival concept, a passionate artistic director, responding to audience feedback and quality facilities. Additionally, planning and managing, community participation and inclusion, and strong, early adoption of market research were important. Crucially, the latter was important in enabling the development of clear festival objectives. The involvement of other external stakeholders and local government support were also seen as important facilitators in success. In summary, this review of festival evolution studies has highlighted their dynamic nature, with crucial factors, including key figures internally as well as externally, and most importantly, the ability to manage and organise successfully.

\section{Research methodology and context}

\section{Research context: Beltane Fire Festival}

Beltane festivals are linked to the Celts as 'in ancient times it was reportedly the Celtic custom to light bonfires on the first of May' (Grimassi 2001, p. 13). There were various components to these festivals, such as the lighting of bonfires, singing, dancing, the sharing of the Beltane cake and, in some cases, the 'Beltane carline' which was the person that underwent a symbolic death (Frazer, 1922). There were variations in the components of these festivals, according to geographical location, for example, in Wales, individuals leapt over the bonfires in order to ensure that there would be a good harvest (Frazer, 1922). The term Beltane meant bright fire among the Celtic people and the bonfires lit during this period were known as 'Need Fires' (Grimassi, 2001). Need-fires were more 
generally a custom for protection and, in specific, ' ... the usual occasion for performing the rite was an outbreak of plague or cattle-disease, for which the need-fire was believed to be an infallible remedy' (Frazer, 1922, pp. 638-639). The 'lighting of Beltane fires ... would recall the growing power of the sun and provide an opportunity to cleanse and renew the conditions of a community - both humans and animals that had spent the dark months indoors' (BFS, 2013). Local fires were extinguished and cattle were often driven around the need-fire as a means of protection (Frazer, 1922). Beltane festivals had taken place throughout Scotland, especially in rural areas, for centuries (Frazer, 1922).

Although the Beltane festivals continued into the modern age, they did decline as various places ended the celebration, particularly in the nineteenth century (BFS, 2013). They ceased to exist in Edinburgh from the early twentieth century (BFS, 2013).

The Edinburgh BFF was resurrected in the late 1980s by a group of cultural community stakeholders (as elaborated upon later) as a means of '...recreating a sense of community and an appreciation of the cyclical nature of the seasons and our connection to the environment' (BFS, 2013). While a festival occurring at the weekend may attract greater audience numbers on a consistent basis, the BFF has remained on a fixed date (30 April). The festival marks the passage of the season and there are strong spiritual overtones. Spiritual roots can also be identified in other festivals, namely the annual Glastonbury Festival of Contemporary Performing Arts (Partridge, 2006). Initially, the event was free and supplemented with fund-raising activities, but it has since moved to a paid ticketing model. To engender inclusion, ticketing prices are low cost. It is primarily volunteers who organise and perform in the festival and this is largely under the auspices of the Beltane Fire Society (BFS), a community organisation with charitable status.

Groups within the performance come in both traditional and modern guises. Two traditional and central components of the performance are the May Queen and the Green Man. The May Queen (see Figure 1) and her White Guard of warriors represent purity, strength and growth, and their procession acts as the vehicle for the core ritual at the heart of the festival. This is represented by the Green Man, a symbol of rebirth and rejuvenation inherent to Spring. Another key group are the Blues, who are elders of the ritual ensuring spiritual continuity in the festival as well as practical advice to organisers and performers alike. A final core grouping is the Reds, who most embody the carnivalesque, representing 'the world Turn'd upside down... [when] fools become kings' (BFS, 2012), in the form of wild and licentious behaviour, and disruption of the May Queen's procession. In addition 


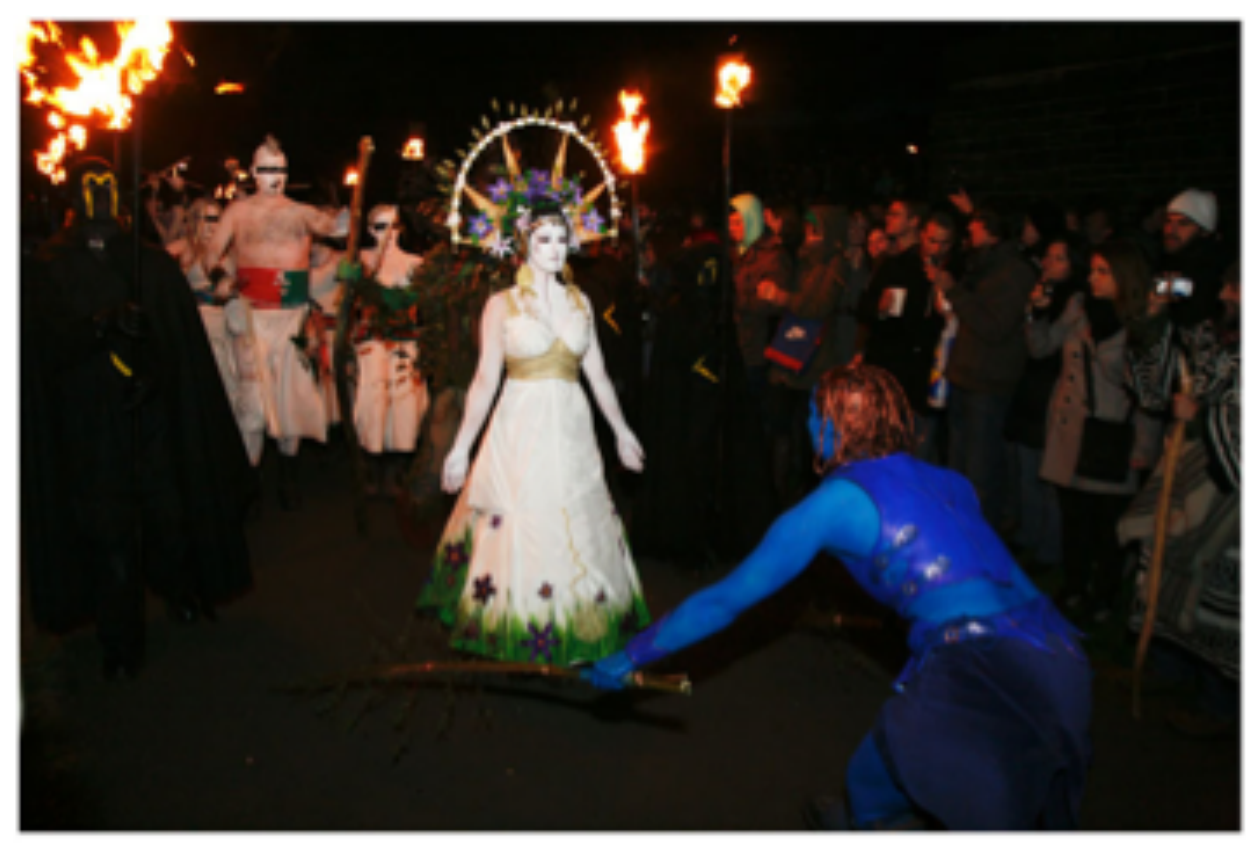

Figure 1. The May Queen.

to these, there are the elemental groups of Fire, Water, Air and Earth, which are each visited in turn by the May Queen and her procession. There are also other performing groups including Fire Arch, No Point, Nightwatch and a storytelling group. The performance includes acrobatics, fire breathing and juggling, accompanied by musical percussion. In all, approximately 300 performers/volunteers take part in the outdoor procession, which starts at dusk and culminates four hours later (BFS, 2013). A survey of the 2011 audience indicated that $95 \%$ of respondents were white, more than half were younger than 30, half were Edinburgh residents with only $30 \%$ coming from outside of Scotland and just over half rejected religious practice. Approximately $75 \%$ of the respondents claimed to either only know a little or had heard informally of the festival and its meaning (Matheson et al., 2014).

\section{Methodology}

The objectives are to: first, identify the stages of the festival's evolution and their respective characteristics; second, distinguish features corresponding to the carnivalesque; and, finally, examine the changes in event evolution, particularly regulatory interventions, and their effect. In common with other studies on the carnivalesque and events (Islam et al., 2008; Kates, 2003; Kates \& Belk, 2001), this study adopted a qualitative approach. The rationale for employing a qualitative approach was because it allows a deeper understanding within the events context (Bryman, 2008, Denzin \& Lincoln, 2005). While a quantitative approach could have been implemented the relatively small population of organisers and performers (approx. 300) would result in a statistically small sample size with the meaningfulness of results questionable, unless a high return rate $(50-80 \%)$ was achieved. The audience was not involved in this particular research, as richer perspectives on the evolution of the festival could be gained from an insider's viewpoint, although subsequent research has involved the audience in motivation and satisfaction contexts 
with the 2011 event (Matheson, Rimmer \& Tinsley, 2014; Matheson \& Tinsley, 2013). As the population was not a 'captured audience', the ability to achieve such a high rate of return would have been less likely to succeed. Furthermore, this aspect of the project focused specifically on the production of the festival and consequently, the data collection centred on key production stakeholders. A series of 11 semi-structured, indepth interviews were conducted in 2010 with internal and external festival stakeholders. This included festival founders and performers, current organisers and performers, police officials, and tourism and cultural policy stakeholders. Clark, Riley, Wilkie, and Wood (1998) highlight that in-depth interviews are most effective when an insight into how individuals or groups perceive the world they live in and how they make sense of the 'reality' that they live in is obtained. The in-depth approach was necessary for the accumulation of useful and 'rich stories' from the respondents. Interviews were supplemented with notes of the performance by the researchers. Both researchers read the transcripts and coding of data was discussed to ensure there was a shared understanding of the underpinning meanings. Data analysis was facilitated through the use of NVivo and thematic analysis (Braun \& Clarke, 2006) was used to interpret the data.

\section{Findings}

\section{Stage 1: Revival and early development}

Stage 1 of the festival's development corresponds to Beverland et al.'s (2001) stages of conception and launch, what Butler (1980) refers to as involvement and exploration. This period can be characterised by the revival of the festival, development and growth of audience numbers, and management issues. At this embryonic stage in the festival's evolution, carnivalesque qualities were most prevalent in the form of a temporary suspension of regulation and the blurring of boundaries between the performers and audience.

The foundations of the festival in terms of purpose, location and content were developed. The BFF revival, led by cultural community stakeholders, occurred because of their interest in festival and public ritual history (see Tinsley and Matheson, 2014 for more on the ritual aspect of the BFF) and their connections to cultural historians and performers. The BFF provided a counter-cultural release from the existing political status quo - the existing Conservative Government - as elaborated upon by a stakeholder:

Beltane wasn't set up as a protest in any sense. Beltane was a release from the mundanity of political struggle where you were really endlessly on the receiving end...I was very clear politically that this was a way that...ordinary people could sort of supersede or expand beyond that grey political landscape. (R1)

Events can be revived to correspond with tourism agendas (Greenwood, 1977; MatthewsSalazar, 2006). In contrast, the BFF's revival was an organic, bottom-up initiative (Quinn, 2006), contributing to the local cultural landscape with a reinterpretation of its predecessor, albeit in a different location. This mirrors Xie and Lane's (2006) notion of organic growth in the early stages of event evolution. 
Situating the festival at the original site raised political issues, 'The original [festival] had taken place on Arthur's Seat...It was owned by the Crown Estates. [This]... would have meant permission from either Prince Charles or Princess Margaret' (R1), which did not sit well with their 'leftist' stance. So an alternative location, Calton Hill, was chosen. While there were associations which already marked the site as carnivalesque through what Ravenscroft and Gilchrist (2009) refer to as 'playful deviance', there were darker undercurrents: '[Calton Hill] had primarily been a place for boy racers, gay murders, it had a bad, a lot of bad stuff happened around that hill' (R1), what Presdee (2000) refers to as the carnival of crime. As such, the festival provided an opportunity to reimage the location (see Figure 2):

[Calton Hill is] owned by the council theoretically on behalf of the good citizens of Edinburgh ... It was a very wonderful stage in terms of the way it talks to the city on a symbolic level and on a physical level. (R1)

Although the original BFF had taken place throughout Scotland (Frazer, 1922), the Edinburgh version had ceased from the early twentieth century (BFS, 2013). The limited documentation about the original festival was used to inform the successor:

We just drew on aspects of the original [Beltane] that had very few historical documents...We weren't going to make a pastiche. We were going to re-initiate something... and then make our version...I also had quite a strong remit to involve Scottish cultural references within it to use the notion of ceilidh ... and bring that out into an outdoors area ... it was very important that it was a celebration within the landscape ... Its roots were agrarian and although we were placing it into an urban context, it was still that notion of connection to a wider landscape. (R1)

Beltane celebrations are rooted in ancient practices, particularly Celtic and pagan, marking the passage of the seasons and symbolising the relationship to the land. Thus, the contemporary BFF is characterised by connections with the previous festival. The importance of key figures (Lade \& Jackson, 2004; Richards \& Ryan, 2004) with a passion for reviving and re-initiating an ancient cultural festival reflects the conceptual stage in event evolution (Beverland et al., 2001). Further, an additional feature of the BFF is the spiritual overtones, given the connections to seasonal change. Spiritual roots are also evident at other festivals, such as the Glastonbury Festival of Contemporary Performing Arts (Partridge, 2006).

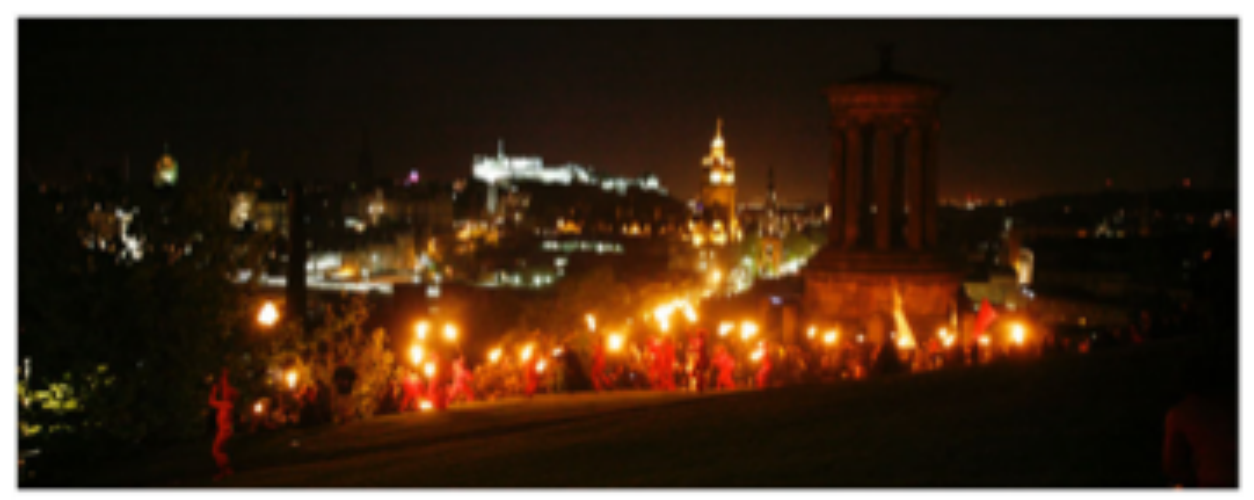

Figure 2. Reds overlooking Edinburgh. 
Performance content changed during this launching stage (Beverland et al., 2001). Initially, the festival was modest in audience numbers and performance content. The '...first modern Beltane saw only five performers take to Calton Hill, watched by an audience of fifty to a hundred people (BFS, 2013). The May Queen has always been part of the performance in contrast to other characters, as noted by a performer: 'right at the beginning there were no white women, no red men, no blue men' (R6). As the festival developed, programme content widened in scope and cultural ambition. Volunteers, both amateur and professional, lead the performance and there was a need to accommodate an increasing number of performers because accessibility is an underlying principle of the festival. This was not without challenges as participants were not necessarily knowledgeable about the festival history, as illustrated by a stakeholder:

Lots of people had an opinion about Beltane but they actually didn't understand its history or what it was about... I felt that that [it] was really important that we understood its symbolism because people wanted to bring in all this other stuff. (R2)

To address this issue, the BFF group collectively came to a consensus about the core and more fluid aspects of the performance. The former led to a consistent performance narrative and the latter provided space for other elements to be incorporated, as illustrated by the creation of the Earth, Water, Air and Fire performance groups.

With regard to carnivalesque features, there was a temporary suspension of regulation and a lack of division between the performers and audience. The festival did not have a specific curfew, which meant the performers and audience could engage with the space as required: 'The early days were ... [about] that whole sense of partying till dawn... It is about being able to sit under the stars till dawn round a fire, absolutely trashed, or still dancing, talking and snogging and all the rest of it' (R2). This temporary suspension of regulatory forces (Bakhtin, 1984a) was partly facilitated by the festival's accessibility as it was non-ticketed. Ticketing is used to control visitor numbers (Beaven \& Laws, 2004) and, in the BFF case, there was little control via such measures. The creation of a free festival was not an unusual development, as free festivals occurred from the 1970s and raves from the 1980s throughout the UK (Partridge, 2006) and, as such, parallels can be made between BFF and the free counter-cultural festival scene. Similarities exist between BFF and the free Stonehenge festival (1974-1984), given their respective spiritual roots, although as mentioned earlier by one stakeholder, the Beltane site unlike Stonehenge was not contested and the festival was a release from the political landscape, which did not take on a form of protest. There are also parallels to rave culture because, as noted by Partridge (2006), free festivals and rave culture assimilated thereby, leading to a fusion of perspectives and spiritualties. Additionally, free festivals did not seek to make a profit (Partridge, 2006), as was the case with the BFF.

Another carnivalesque feature during this conception and launch stage (Beverland et al, 2001) was the lack of division between performers and the audience (Bakhtin, 1984b), as illustrated by a BFF stakeholder:

When the festival was smaller there was just less of a kind of division between performers and audience because everybody was just up all night and once the performance was over the 
boundaries between audience and performer disappeared... Everybody would just be hanging around the fire and jumping the fire and doing whatever they were doing and [there would be] little outbreaks of drumming and chanting and different things happening around the hill all night ... . this completely anarchic sort of vibe of just taking over the hill. (R4)

These changes in social relations and boundaries correspond to Bakthtin's (1984b) assertion that distinctions between performers and audience were abandoned during carnival as well as more contemporary analyses delineating the blurring of boundaries between performers and audience (Harcup, 2000; Islam et al., 2008; Langman, 2003a). These interactions were not always social as there could be a violent undertone. Verbal aggression could be directed at performers by audience members, as illustrated by the following: 'I remember there were some people shouting "Wanker! Wanker! You're a wanker!" [at me] and I just kept going' (R6). At times, such aggression could occur in a more extreme form, as noted by an organiser:

There was a lot of rougher people when it was free ... [There was a] violent undertone which never manifested too often but it was there ... [One] year ... there were people with knives and just horribly drunk people grabbing at the drummers and there was someone on the top of the tent who had slid down the tent and ripped huge holes. (R1)

Such disorder also reflects carnivalesque qualities as a period of disorder (Presdee, 2000; Rogers, 2002), which has contributed to its repression (Stallybrass \& White, 1986). Yet, the aforesaid quote reveals organiser perceptions of the implications of a free festival. A free festival is undeniably accessible, but there was a perception that a group of the audience were overtly aggressive. This 'edge' to the festival was problematic for organisers, but was emblematic of carnivalesque features. The carnivalesque that Bakthin (1984a, 1984b) depicted was not a time of order and convention but the opposite, particularly in circumstances characterised by a lack of regulatory intervention. However, as the festival developed it become incumbent on organisers to implement control measures which changed the audience, as will be seen in the following growth stage (Beverland et al., 2001).

The BFF audience grew exponentially while the organisers did not have a ticketing policy to control demand. Growth occurred on a rapid basis, for different reasons, as denoted by the following:

[It was] absolute word of mouth but it did go 200, 600, 1000, 3000 and then it just kept getting bigger ... Maybe [the growth occurred] because ... it's annual ... and ... it's authentic, raw and genuinely quite wild at times ... There's the hedonistic side and the sex and drug taking or being excessively drunk ... For some members of the audience that's all it is [but] ... there's very many other people for whom something genuinely transformational is happening under that structure. (R1)

This provides an explanation for festival growth in terms of the audience and word of mouth. With regard to the audience, periods of temporary excess often accompany the suspension of regulation and social conventions during the carnivalesque (Bakhtin, 1984b) and recur within contemporary analyses (Gilmore, 1995; Kates, 2003; Langman, 
2008). Yet, it would be remiss to interpret such a festival as solely being about excess, as they also offer participants an opportunity to engage with personal change which could be transformational in nature. Indeed, MacAloon (1984, p. 1) suggested that festivals could be 'occasions where as a culture or society we can reflect upon and define ourselves, dramatise our collective myths and history, present ourselves with alternatives, and eventually change in some ways while remaining the same in others'.

Word of mouth can be a powerful marketing tool, as noted by Chen's (2009) analysis of the Burning Man festival, and the uniqueness of the BFF also played a part in its growth. Such growth posed challenges, given issues about adhering to health and safety principles (Silvers, 2007; Tarlow, 2002) and the level of audience-performer engagement. As illustrated earlier, there was a lack of division between performers and audience (Bakhtin, 1984b), yet this raised risk management issues, as noted by the following organiser: 'They would just hand out (fire) torches to people in the audience to carry round and I remember somebody on the Acropolis throwing their torch into the audience and going "Oh my God", (R2). Such practices raise not only risk management issues but illustrate gaps in festival organisation. Similarly, Chen (2009) highlighted organisational challenges when the Burning Man festival was first developed, to the extent that it entered into the realms of disorder. Indeed, the Burning Man festival had similar informal and volunteerbased origins to the BFF.

\section{Stage 2: Further development and regulation}

Stage 2 of the festival's development corresponds to the growth (Beverland et al., 2001) or development (Butler, 1980) stage, reflecting more formalised structures and management, with a significant change in the festival's nature from the first stage. For Beltane, this period was characterised by greater regulatory pressures, changes to the event-funding model and features of the carnivalesque were increasingly subject to control.

The festival was subject to internal and external drivers of regulation. Internally, a community-focussed society, the BFS was created and gained charitable status. This status contributed to the festival's professionalisation (Richards \& Ryan, 2004), particularly financially with funding being a key challenge in a festival's evolution (Getz, 2002). Further, issues of liability could have had profound implications for organisers, particularly without professionalised status, as noted by an organiser: '[BFS] needed to be a company limited by guarantee. It had to have that status because if anything went wrong, the people's names who were on it - it was a heavy burden' (R2). On the one hand, the shift to a charitable status organisation reflects wider changes whereby festivities commencing operations on an informal management and organisational basis are frequently compelled to embrace professionalised management structures, if they are to continue. For example, the Burning Man festival (USA) began on a small-scale, informal basis and, as it developed, adopted a formalised management structure comprising a legal partnership (Chen, 2009). On the other hand, the regulation and professionalisation of the BFF is anathema to Bakhtin's (1984a, 1984b) conceptualisation of the carnivalesque, which emphasised an organic, bottom-up approach characterised by 
freedom from social conventions and mores. A defining feature of the carnivalesque was a suspension of regulation and, in the BFF case, the adoption of regulatory influence illustrates the ways in which carnivalesque aspects have been subject to a civilising process. This is not an unusual development, as festivals have long been exposed to civilising influences (Presdee, 2000; Rojek, 1995; Stallybrass \& White, 1986) to curb their excesses.

With regard to external drivers, there were new stakeholder relationships (Quinn, 2005), as the BFF was subject to greater regulatory intervention, as noted by an organiser:

We always had a few stewards, but then the new regulations started coming in ... Beltane became subject to EPOG (Edinburgh Planning and Operations Group)...[and] that had a big influence on the event ... There was lots of health and safety things that did need to be addressed or thought about. It was always very shaky. (R2)

As articulated in Stage 1, there were specific health and safety concerns and EPOG interventions meant they had to be rectified. Organisers were obliged to adhere to regulatory requirements and the production and control of the performance changed. For example, fires were fenced off for health and safety reasons, curfews were imposed and, in addition, organisers had to demonstrate their expertise to regulatory authorities, as noted by an organiser: '... we had to get the trust of the council and the authorities ... We had to prove that we knew better how to deal with crowds and ... flows of people than they did' (R2). This tension also played out during the performance itself: 'when you're confronting police [about crowd flow] painted blue and your tits are out and you've got big sticks in your hand and they're just standing there (R2). Health and safety issues were also raised regarding consumption as: 'there was a vast amount of drug taking and drinking on the hill' (R2). Thus, there was a tension between the transgression of social norms, as is so often highlighted in depictions of the carnivalesque (Kates, 2003; Presdee, 2000) and accompanying health and safety requirements.

Changes in regulatory interventions were not exclusive to BFF, rather it was symptomatic of broader regulatory management changes. The regulation of leisure and cultural activities has a deep-seated history (Rojek, 1995; Stallybrass \& White, 1986) and, more recently, there have been significant regulatory developments impinging on events, most notably around health and safety management (Bowdin, Allen, O'Toole, Harris, \& McDonnell, 2006; HSE, 1999). Invariably, such changes necessitate compliance with risk management and associated regulatory frameworks, as is the case with the BFF and other events. Similarly, the Burning Man event complied with increasing regulation, such as recreation permits and insurance, amid safety concerns as the event evolved (Chen, 2009). Although risk management and regulatory interventions contribute to the health and safety of the audience, there is a tension as these interventions can impede cultural activities. For instance, the 1994 Criminal Justice and Public Order Act curtailed outdoor rave activities (Critcher, 2000; Partridge, 2006). In a wider context, commentators have examined the implications of aspects of risk management, such as, event consumers perception of risk (Boo \& Gu, 2010), particularly terrorism related (Taylor \& Toohey, 2006, 2007); management of event security (Cieslak, 2009); insurance effect on festivals 
(Arcodia \& McKinnon, 2004); types of risk management strategies employed by event stakeholders (Leopkey \& Parent, 2009); and event managers attitudes toward risk management (Reid \& Ritchie, 2011). As noted by Getz (2002), regulations and legal constraints can contribute to the failure of festivals. Thus, the BFF's compliance with regulatory frameworks meant that it was in a position to address underlying health and safety concerns, thereby safeguarding its future, especially as audience numbers continued to grow.

Nevertheless, compliance with risk management was not without challenges. There were financial increases because of event growth, associated production cost increases and specific regulatory costs, as exemplified by the following:

When the regulations ... came in you have to pay for them and eventually donations through bucketing [did not] cover it ... The biggest one was public liability insurance because after 9/11 premiums on those things rocketed...So it was that plus another couple of licences...but it [had] also got to the scale that even our staging cost thousands. (R9)

Increases in public liability insurance can have a considerable effect on festivals (Arcodia \& McKinnon, 2004) and for BFF, this led to changes in the event-funding model.

Originally, the BFS was reliant on fund-raising events and donations to support the event; however, an emphasis on a free, non-commercialised event coupled with cost increases meant that the funding model was unsustainable. While Getz (2000) has argued that such funded events are less likely to be vulnerable to competition and age, there was nevertheless a crisis point, which resulted in an important evolutionary moment. Mounting tensions were finally exacerbated when the public performance was temporarily cancelled one year for a range of reasons, in particular funding. 'We couldn't afford the insurance money ... We couldn't afford that as well as the council asking us for increased money for various things for licences' (R3). The impact of spiralling costs is not unsurprising, given BFF's funding model. Increases in Australian insurance costs also contributed to the cancellation and postponement of a number of rural festivals (Arcodia \& McKinnon, 2004).

In effect, the BFS was obliged to move to a ticketed event to meet event costs and staging:

There was this intense clamping down on everything and insurance for all our fire performance and everything went up about $1000 \%$... Everything just became harder and the police were more controlling ...It just seemed inevitable if we were going to be on Calton Hill, with those numbers of people attending and with all the massive costs associated with putting it on ... that ticketing was how it had to be. (R4)

This evolution by overcoming a funding crisis (Beverland et al., 2001; Getz, 2002) brought benefits, including financial stability, continued staging on Calton Hill and audience changes. Yet, within the BFS confines, the shift to a ticketing model '... was quite controversial at the start but really the choice was do it or don't do Beltane' (R3). Ticketing provided income generation (Beaven \& Laws, 2004) and financial stability meant the festival could continue on the Calton Hill site. Event cancellation had 
accentuated the significance of place: 'Coming back ... on the hill [after the cancellation] felt very special and you realised that the place was special, that taking it somewhere else, it didn't work in the same way' (R2). Akin to many festivals, the BFF is bound to a sense of place that is fundamental to its identity (Derrett, 2003; Duffy 2000). The cancellation is an example of what Richards and Ryan (2004, p. 115) refer to as 'forces of creative destruction' when internal and external stakeholders clashed and a subsequent overcoming of the crisis, ensuring the festivals continued development and evolution. Another indirect ticketing effect was a shift in the audience: 'It's a much nicer audience, calmer, not the nasty edge, not really pissed people. Not the ones coming out to cause trouble' (R3). While this audience change may have been beneficial for the management, as noted earlier, the 'edge' to the festival was also representative of the carnivalesque.

Additional regulation addressed risk management concerns while simultaneously controlling the carnivalesque. Adopting a ticketing policy was a double-edged sword, in that: 'It brought money in ... [but] it also did a bad thing. It removed that sense of controlled anarchic freedom' (R11). Similarly, Kozinets (2002, p. 24) noted that regular participants of the Burning Man event had identified that '...the event had become far too rule-bound and had lost its wildness', thereby losing an aspect of its quintessential essence. Temporary freedom, particularly anarchic, is a key feature of Bakhtin's (1984a, 1984b) thesis and, in the modern world, is subject to regulation particularly as a means of social control (Gilmore, 1998; Ravenscroft \& Matteucci,

2003). Curtailment of carnivalesque qualities can also be identified with changes in the audience and performer relations and the performance itself. Although a carnivalesque feature of the festival had been the lack of division between performers and audience, as articulated in Stage 1, regulation changed the social experience:

Once things became more controlled [with] curfews [and we] had to be off the hill by one [am]...you know that [performer-audience relationship] sort of started breaking down. So it was really just about the performance the audience comes to and then everybody leaves. So there aren't then those blurred boundaries around who is watching and who is performing. (R4)

The audience observed the carnivalesque, rather than participating in it. During Stage 1, participants could engage in the backstage region of social space which MacCannell (1999) described and both performers and audience could participate in authentic social relations. Regulatory changes in Stage 2 reduced these participatory social relations as audience members had little prospect of engaging with performers in the same way; instead, their engagement was observation rather than participation. Such an occurrence is not uncommon as Greenwood (1977) highlighted the ways in which a public ritual was altered through tourism commodification and, in this case, it is largely regulatory change that led to a dilution of carnivalesque qualities and authentic social relations. During this period, these qualities were perceived to have irrevocably changed. For the 'old Beltane guard', this was a difficult turning point: '[They] did feel at the time, that the spirit had gone out of the festival and not being able to stay up the hill all night and drum and dance 'till dawn ... that Beltane was not what it was' (R4). Thus, these wider regulatory interventions had an effect on the festival's meaning. While Stage 1 was characterised by 
meaningful social relations between audience and performer, fluidity in the boundaries between the two and limited intervention from other stakeholders, the significant regulatory changes occurring in Stage 2 had an effect on the shape and character of the festival. The crisis which occurred and the subsequent overcoming of these issues with a new ticketed funding model ensured the festival's evolution to the next stage.

\section{Stage 3: Maturation}

Stage 3 of the festival's development corresponds to the consolidation stage (Beverland et al., 2001; Butler, 1980) reflecting the festival's maturation. This stage can be characterised by the festival's professionalisation and a ticketed funding model. In addition, the festival has reached a mature point in its life cycle with a steady volunteer and audience base. The artistic core of the festival has matured while retaining features of the carnivalesque in performance aspects.

The BFF has developed a professionalised management approach which extends to its stakeholder relationships and this is reflected in mature working relations. Greater professionalisation (Anderton, 2011) is not only the domain of private and public sector events as "a "grassroots" event does not preclude the adoption of a formal or professional approach' (Richards \& Ryan, 2004, p. 96). A professionalised approach began in Stage 2 when the BFF gained charitable status and experience in managing regulatory pressures. This led to the development of a professionally managed event. Likewise, the Glastonbury Festival of Contemporary Performing Arts has evolved from grassroots origins to a professionalised event because of audience size and increasing legislation (Flinn \& Frew, 2013). For BFF, risk management challenges identified in Stages 1 and 2 have largely been addressed with compliance to legal and regulatory requirements. As noted by an external stakeholder, the event is a 'successful one' and 'it's a relatively straightforward gig' (R5). Although there were historical tensions between the BFF and regulatory stakeholders, relationships are now positive, as illustrated by the following:

I thought there was a bit of antagonism. Now there has been in the past ... I think they [local council] are pretty much aware of the worth of Beltane to the city and to Scotland in general ... They are very, very supportive. (R9)

Thus, as the festival has evolved and developed its audience base, there is greater awareness among stakeholders about the contribution of the event to the local cultural landscape.

The event-funding model is largely self-reliant and is neither dependent on public funding nor sponsorship. Previously, it had acquired limited funding from grants and sponsors and it currently relies on fund-raising activities and income generation from ticketing. The majority of event roles are undertaken on a voluntary basis, as there are few paid positions within the organisation, thereby reducing costs (Getz, Andersson, \& Carlsen, 2010). There is a certain ambivalence about seeking sponsorship and, in contrast to other events (Finkel, 2010), the BFF has resisted commercialisation. Although there are commercial pressures on contemporary festivities (Anderton, 2008), some have maintained a non-commercial stance, such as the Glastonbury Festival of Contemporary 
Performing Arts (Flinn \& Frew, 2013) or the Burning Man festival (Kozinets, 2002; Kozinets \& Sherry, 2004) because it is fundamental to their identity. In an international festival survey, it was noted that not-for-profit festivals generally do not receive a high proportion of their income from local government grants (Getz et al., 2010) and there is little scope for BFF to attain this given funding cuts and criteria, as illustrated by an external stakeholder: 'For organisations like Beltane it's very difficult at the moment because there's no way in [to get funding] because everyone else is being cut so it is difficult' (R8). An additional funding barrier relates to BFF's size. There is a strategic issue as Edinburgh has an umbrella organisation, Festivals Edinburgh, to encompass the strategic needs of the city's twelve major festivals; however, the BFF does not fall under its remit because it is a small-scale festival. This suggests that smaller festivals in the city are being overshadowed by their larger counterparts, which is not uncommon within the sector. Although the BFF receives little in the way of external financial support, it has been able to operate on a sustainable basis because of their management approach.

The festival's longevity stands as testimony to its volunteer and audience base. As with other events (Elstad, 2003; Kemp, 2002; Monga, 2006), the BFF is dependent on volunteers to undertake operational and performance roles. Yet, the contribution of volunteers also has a symbolic value which signifies inclusivity and local community support (Quinn, 2003). For volunteers, there can be a sense of community, particularly for those that volunteer on a long-term basis. Nevertheless, there are retention issues, especially among those with management responsibilities and volunteer burnout can threaten the festival's longevity (Getz, 2002), as noted by the following stakeholder:

People would give their all to it and they would put in hundreds of hours ... especially in the lead up to the Beltane festival. It was always a huge amount of work and a lot of responsibility, particularly for those who were shouldering it and...when you've got to do all that alongside holding down a job and paying rent or whatever ... it does take its toll on you. (R4)

The volunteer base is critical to festival production as are the audience to its consumption. Yet, there are challenges encompassing the audience base. Stages 1 and 2 illustrated audience growth and ticketing controlled visitor numbers which is especially important as the site has a carrying capacity. Yet the maintenance of the audience base is challenging, given the preponderance of first-time visitors, as noted by an internal stakeholder:

$75 \%$ of people have never been before [to the festival]. That's a lot. That speaks volumes for [an] inability to be able to keep people there but on the flipside it means it's something people see as essential to do in Edinburgh. (R9)

The reference to $75 \%$ of the audience as first-time visitors is based on Gonzalez's (2007) survey of the BFF audience. A further survey (Matheson et al., 2014) on the 2011 BFF also indicated the audience comprised a high proportion of first-time visitors $(80.4 \%)$, thereby suggesting a lack of repeat visitation. Thus, while the festival has reached a mature stage, there are production and consumption issues that could comprise its sustainability. An additional production issue relates to the artistic core. 
The artistic core has evolved as other elements have been incorporated into the festival, as noted by an internal stakeholder: 'the concept was realised twenty years ago, so ... there is a lot of space for people to deal with where they fit into that' (R11). The cultural evolution of the BFF has not been without accompanying issues. Initially, professional performers led the performance; however, as the festival evolved this changed. The performance is primarily made up of non-professional performers which relates to the festival's inclusive and community-orientated philosophy. Although the festival adopted a more professionalised management approach, this has not extended to the performance. The emphasis on non-professional performers has raised tensions about performance quality. Furthermore, the introduction of ticketing can raise audience expectations about performance quality. Consequently, tensions exist between: ' ... being an all-inclusive organisation and the fact that you are actually providing a paying audience to come and witness something that needs to be of a certain quality' (R11). An additional change to the nature of the performance relates to its technique. As the performance evolved, the technique changed as exemplified by the following: 'The way [the] production was being run, it's just highly sophisticated, an evolution of technique over time...The loss of course is it's less raw, it's less anarchic ... - it loses a bit of its danger and wildness but I still think the core's pretty strong' (R1). Hence, the anarchic and carnivalesque features of the performance have been diluted as the festival has matured. Likewise, the Burning Man event has undergone a similar evolutionary process as '... organisers redirected the event away from the anarchist activities and ideology that were popular with some eventgoers' (Chen, 2009, p. 32). Despite these changes, carnivalesque features remain within the performance.

Within its artistic core, the festival provides a space for performers to express themselves freely, without restraint and to transgress social conventions within the carnivalesque space: 'Beltane is that little pocket where people can express themselves in a very free, vibrant and uncontrolled way, it's very exciting, it doesn't happen that often' (R1). This is particularly apparent in aspects of the performance which display partial nakedness: 'The nakedness only extends to certain groups but then it also depends on what year it is. Sometimes for the elements [performance groups] it's pretty much 50-50 as to whether or not they go topless or not and it's down to the members of the group. The Reds are always naked because that is just what they do' (R9). Similarly, the New Orleans Mardi Gras contains elements of public nudity; however, in that particular case, there were tensions regarding the implications for the meaning and commodification of the event (Gotham, 2005). It is the Red group that bears most similarities to the carnivalesque spirit (Bakhtin 1984a). Just as Bakhtin documented 'the reverse side of the world' (1984a, 1984b, p. 122), the 'Reds are the Lords and Ladies of Misrule. Beltane is their night of mischief the World Turn'd Upside Down - the one night of the year where fools become kings' (BFS, 2012). As described by BFS (2012), they represent 'the need in all of us to let loose and go wild just once in our lives', which also embodies the spirit of carnival. Indeed, 'the way of [the] Reds is always bacchanalian, free, liberated sexual[ly], just scuzzy and having a really good time as opposed to the tightness and formality of others' (R1). Thus, the BFF performance itself retains carnivalesque features with its 
temporary freedom, transgression from societal conventions and moments of licentiousness.

\section{Conclusion}

This paper has identified key stages in the BFF's evolution, carnivalesque features and the effects of regulatory interventions. It is evident that evolutionary stages have largely been in keeping with themes documented in the literature, namely introduction, development and growth, and maturity (Beverland et al., 2001; Richards \& Ryan, 2004). Stage 1 was the period when the festival was first revived and developed. The foundations of the festival were laid in terms of its content, meaning and location. When the festival first commenced it was very much a small-scale event, in terms of production and consumption; however, this changed as the festival grew in popularity, not only among consumers, but also among volunteers wishing to participate in the festival. Consequently, such demand placed significant pressures on management and furthermore, there was limited regulatory intervention in the way of control measures to harness this demand. Despite these challenges, this was also the period when the carnivalesque was especially apparent in the form of a temporary suspension of regulation and the blurring of boundaries between the performers and audience.

Stage 2 was a period of further development and regulation. This period was undoubtedly characterised by greater regulation, both internal and external. The festival became increasingly professionalised, as illustrated by the move to acquiring charitable status. On an external basis, and in common with other leisure and cultural activities, the festival was required to adhere to greater regulatory interventions. Compliance with regulatory intervention had implications for the production and consumption of the event. Increasing production and regulatory costs had significant consequences for the event, which is not an unusual effect of regulatory change (Arcodia \& McKinnon, 2004). The long-term effect of cost increases was a change in the event-funding model, whereby the festival moved from a free non-ticketed event to a costed ticketed event. With regard to the carnivalesque, regulatory effects had a profound effect. The separation between performers and the audience became more apparent and the opportunity to transgress social norms was curtailed because of the imposition of a curfew and regulatory mechanisms. Bakhtin (1984a) argued that regulatory mechanisms were suspended for the duration of the carnivalesque, and while there was evidence of this occurring in the previous stage of the BFF's evolution; this stage was instead characterised by significant regulatory mechanisms.

Stage 3 was a period of maturation for the festival. Management adopted an increasingly professionalised approach, most notably in the engagement with external stakeholders and expertise in dealing with regulatory requirements, as festival practices were consolidated. Management maintained an independent approach to funding the festival and it is, in essence, sustainable through ticketing and internal mechanisms of income generation. An additional feature of the festival's sustainability is its volunteer base, without which it would cease to exist, and its continued attraction for potential consumers. Nevertheless, the preponderance of first-time visitors indicates that there are issues pertaining to 
consumer retention. Carnivalesque features are evident in the performance as performers are afforded an opportunity to temporarily transgress social convention. The period when the carnivalesque offered greater participation for all and a lack of division between performers and audience has been eroded with the onset of regulatory influences and increased audience size. Thus, the carnivalesque has evolved to become a spectacle.

The implications of this paper are twofold, being both practical and theoretical. First, the evolution of the BFF resonates, to an extent, with similar festivals thereby suggesting that events can undergo comparable developmental stages. Certain parallels can be made to the Burning Man event. Although the BFF is not of a comparable scale or size to the Burning Man event, there are some distinct similarities. The Burning Man also started on an organic basis and changed its organisational practices, in particular, to accommodate regulatory requirements (Chen, 2009). It is also reliant on a volunteer base (Kozinets, 2002) and has some pagan influences (Kozinets \& Sherry, 2004). As with the BFF, the Burning Man has undergone evolutionary changes from its introduction through growth and maturity. There are also similarities with the Glastonbury Festival of Contemporary Performing Arts which has spiritual roots (Partridge, 2006) and went through an evolutionary shift from a grassroots to a professionalised event (Flinn \& Frew, 2013). Thus, given that there can be some parallels in the evolutionary cycle of events, especially if they are similar, and that there can be certain commonalities in internal and external drivers to change, for example, regulatory intervention, then this can be used as a means to inform other events, particularly as a means of developing adaptive strategies and solutions for managing change. Second, there are theoretical implications in terms of highlighting the continued value of the carnivalesque and the event evolution lifecycle model. This study has illustrated that the BFF retains features of the carnivalesque although these have changed as the festival has evolved and been subject to regulatory pressure. Hence, this study supports Ravenscroft and Gilchrist's (2009) contention that the carnivalesque has validity in contemporary life; indeed, Bakhtin (1984a) asserted that the carnivalesque was indestructible. Finally, although the event evolution life-cycle model is not predictive (Getz, 2000), it can be a useful tool to ascertain the development trajectory of events and the ways in which internal and external drivers can influence developmental stages. Nevertheless, there are limitations associated with the life-cycle model in that it does not necessarily capture all the developmental stages; indeed, as noted by Getz (2002) events can be moved or temporarily cancelled. Certainly, in the case of the $\mathrm{BFF}$, the event was temporarily cancelled during the further development and regulation stage thereby illustrating that the life-cycle model is neither necessarily linear or predictive, which is in line with other findings (Beverland et al., 2001; Quinn, 2006; Richards \& Ryan, 2004; Xie \& Lane, 2006). The final maturation stage of BFF highlights many of the qualities which Getz and Andersson (2008) refer to in identifying a sustainable festival: managerial success in terms of the volunteer organisers and performers, market popularity with stable attendance figures and longevity, political support in terms of EPOG and Edinburgh City Council, and resources in terms of a viable long term funding model. 


\section{Notes on contributors}

Catherine Matheson is a senior lecturer in Events Management at Queen Margaret University. Her research interests are in event development, motivation and satisfaction, event-led urban regeneration strategies and human rights and events.

Ross Tinsley is the head of research at the Hotel and Tourism Management Institute (HTMi). His research interests are in the identity and evolution of counterculture events, social anthropology and qualitative methodology. He has also researched and published on small tourism businesses and destination development within developing country contexts. His current work centres on the evolution of the Beltane Fire Festival, of which he was a past performer.

\section{References}

Anderton, C. (2008). Commercialising the carnivalesque: The V festival and image/risk management. Event Management, 12, 39-51.

Anderton, C. (2011). Music festival sponsorship: Between commerce and carnival. Arts Marketing: An International Journal, 1, 145-158.

Arcodia, C., \& McKinnon, S. (2004). Public liability insurance: Its impact on Australian rural festivals. Journal of Convention and Event Tourism, 6, 101-110.

Bakhtin, M. (1984a). Rabelais and his world. (Hélène Iswolsky, Trans.). Bloomington: Indiana University Press.

Bakhtin, M. (1984b). Problems of Dostoevsky's poetics. (Caryl Emerson, Trans.). Manchester, NH: Manchester University Press.

Beaven, Z., \& Laws, C. (2004). Principles and applications in ticketing and reservation management. In I. Yeoman, M. Robertson, J. Ali-Knight, S. Drummond, \& U. McMahon-Beattie (Eds.), Festival and events management: An international arts and culture perspective (pp. 183201). Oxford: Elsevier Butterworth-Heinemann.

Beltane Fire Society (BFS). (2012). The reds. Retrieved November 25, http://beltane.org/ about/ reds/

Beltane Fire Society (BFS). (2013). A detailed history of Beltane. Retrieved November 14, 2013, from http://beltanefiresociety.wordpress.com/a-detailed-history-of-beltane/

Beverland, M., Hoffman, D., \& Rasmussen, M. (2001). The evolution of events in the Australasian wine sector. Tourism Recreation Research, 26, 35-44.

Boissevain, J. (1996). Ritual, tourism and cultural commodification in Malta. In T. Selwyn (Ed.), The tourist image: myths and myth making in tourism (pp. 105-120). Chichester: John .

Boo, S., \& Gu, H. (2010). Risk perception of mega-events. Journal of Sport and Tourism, 15, 139161.

Bourdieu, P. (1984). Distinction: A social critique of the judgement of taste. London: Routledge \& Kegan Paul. 
Bowdin, G. A. J., Allen, J., O’Toole, W., Harris, R., \& McDonnell, I. (2006). Events management. Oxford: Elsevier Butterworth-Heinemann.

Braun, V., \& Clarke, V. (2006). Using thematic analysis in psychology. Qualitative Research in Psychology, 3, 77-101.

Bryman, A. (2008). Social research methods. Oxford: OUP.

Butler, R. W. (1980). The concept of a tourist area cycle of evolution: Implications for management of resources. Canadian Geographer/Le Géographe Canadien, 24, 5-12.

Chen, K. K. (2009). Enabling creative chaos: The organisation behind the Burning Man event. Chicago, IL: University of Chicago Press.

Cieslak, T. J. (2009). Match day security at Australian sport stadia: A case study of eight venues. Event Management, 13, 43-52.

Clark, M., Riley, M., Wilkie, E., \& Wood, R. (1998). Researching and writing dissertations in hospitality and tourism. London: International Thomson Business Press.

Connor, G., \& Farrar, M. (2004). Carnival in Leeds and London: Making new black British subjectivities. In M. C. Riggio (Ed.), Culture in action: The Trinidad experience (pp. 255-269). New York, NY: Routledge.

Critcher, C. (2000). 'Still raving': Social reaction to ecstasy. Leisure Studies, 19, 145-162.

Denzin, N. K., \& Lincoln, Y. S. (2005). The sage handbook of qualitative research (3rd ed.). London: Sage.

Derrett, R. (2003). Making sense of how festivals demonstrate a community's sense of place. Event Management, 8, 49-58.

Duffy, M. (2000). Lines of drift: Festival participation and performing a sense of place. Popular Music, 19, 51-64.

Elstad, B. (2003). Continuance commitment and reasons to quit: A study of volunteers at a jazz festival. Event Management, 8, 99-108.

Festivals Edinburgh. (2013). Edinburgh's festivals: Defining scotland's cultural identity on the global stage. Edinburgh: Author. 
Finkel, R. (2010). Re-imaging arts festivals through a corporate lens: Case study of business sponsorship at the Henley Festival. Managing Leisure, 15, 237-250.

Flinn, J., \& Frew, M. (2013). Glastonbury: Managing the mystification of festivity. Leisure Studies, $1-16$.

Frazer, J. (1922). The golden bough: A study in magic and religion. New York, NY: Macmillan.

Getz, D. (1993). Corporate culture in not-for-profit festival organisations: Concepts and potential applications. Festival Management and Event Tourism, 1, 11-17.

Getz, D. (2000). Festivals and special events: Life cycle and saturation issues. In W. C. Gartner \& D. W. Lime (Eds.), Trends in outdoor recreation, leisure, and tourism (pp. 175-185). Wallingford, Oxon: CABI.

Getz, D. (2002). Why festivals fail. Event Management, 7, 209-219.

Getz, D. (2008). Event tourism: Definition, evolution, and research. Tourism Management, 29, 403428.

Getz, D., \& Andersson, T. D. (2008). Sustainable festivals: On becoming an institution. Event Management, 12(1), 1-17.

Getz, D., Andersson, T., \& Carlsen, J. (2010). Festival management studies: Developing a framework and priorities for comparative and cross-cultural research. International Journal of Event and Festival Management, 1,29-59.

Gilmore, D. D. (1995). The scholar Minstrels of Andalusia: Deep oratory, or the carnivalesque upside down. Journal of the Royal Anthropological Institute, 1, 561-580. Gilmore, D. D. (1998). Carnival and culture: Sex, symbol and status in Spain. London: Yale University Press.

Gonzalez, R. (2007). Beltane Fire Festival: Inaugural economic and audience profile assessment. Edinburgh: Beltane Fire Society.

Gotham, K. F. (2005). Theorising urban spectacles: Festivals, tourism and the transformation of urban space. City, 9, 225-246. 
Greenwood, D. J. (1977). Culture by the pound: An anthropological perspective on tourism as cultural commodification. In V. L. Smith (Ed.), Hosts and guests (pp. 129-139). Philadelphia, PA: Philadelphia University Press.

Grimassi, R. (2001). Beltane: Springtime rituals, lore and celebration. St Paul: Llewlleyn. Hanlon, K. B. (2004). Inside shock music carnival: Spectacle as contested terrain. Critical Sociology, 30, $743-778$.

Harcup, T. (2000). Re-imaging a post-industrial city: The Leeds St Valentine's Fair as a civic spectacle. City, 4, 215-231.

Health and Safety Executive (HSE). (1999). The event safety guide: A guide to health, safety and welfare at music and similar events. Norwich: Health and Safety Executive.

Higham, J. E. S., \& Ritchie, B. (2001). The evolution of festivals and other events in rural southern New Zealand. Event Management, 7, 39-49.

Islam, G., Zyphur, M. J., \& Boje, D. (2008). Carnival and spectacle in Krewe de Vieux and the mystic Krewe of Spermes: The mingling of organisation and celebration. Organisation Studies, 29, $1565-1589$.

Kates, S. M. (2003). Producing and consuming gendered representations: An interpretation of the Sydney gay and lesbian Mardi Gras. Consumption, Markets and Culture, 6, 5-22.

Kates, S. M., \& Belk, R. W. (2001). The meanings of lesbian and gay pride day: Resistance through consumption and resistance to consumption. Journal of Contemporary Ethnography, 30, 392-429.

Kemp, S. (2002). The hidden workforce: volunteers' learning in the Olympics. Journal of European Industrial Training, 26, 109-116.

Kozinets, R. V. (2002). Can consumers escape the market? Emancipatory illuminations from burning man. Journal of Consumer Research, 29, 20-38.

Kozinets, R. V., \& Sherry, J. F. (2004). Dancing on common ground: exploring the sacred at burning man. In G. St. John (Ed.) Rave culture and religion. (pp. 287-303). London: Routledge.

Lade, C., \& Jackson, J. (2004). Key success factors in regional festivals: Some Australian experiences. Event Management, 9(1-1), 1-11.

Langman, L. (2003a). Culture, identity and hegemony: The body in a global age. Current Sociology, $51,223-247$.

Langman, L. (2003b). The ludic body: Ritual, desire and cultural identity in the American Super Bowl and the Carnival of Rio. In R. H. Brown (Ed.), The politics of selfhood: bodies and identities in global capitalism (pp. 64-86). Minneapolis, MN: University of Minnesota Press. 
Langman, L. (2008). Punk, porn and resistance: Carnivalisation and the body in popular culture. Current Sociology, 56, 657-677.

Leopkey, B., \& Parent, M. M. (2009). Risk management strategies by stakeholders in Canadian sporting events. Event Management, 13, 153-170.

Levitt, T. (1965). Exploit the product life cycle. Harvard Business Review, 11, 81-94. Lindahl, C. (1996). Bakhtin's carnival laughter and the Cajun country Mardi Gras. Folklore,

107, 57-70.

MacAloon, J. J. (1984). Introduction: Cultural performances, culture theory. In J. J.

MacAloon (Ed.), Rite, drama, festival, spectacle: rehearsals towards a theory of cultural performance (pp. 1-15). Philadelphia, PA: Institute for the Study of Human Issues. MacCannell, D. (1999). The tourist: A New theory of the leisure class. Berkley, CA: University of California Press.

Matheson, C. M. (2008). Music, emotion and authenticity: A study of Celtic music consumers. Journal of Tourism and Cultural Change, 6, 57-74.

Matheson, C. M., \& Tinsley, R. (2013). Regulating community festivals: Audience experiences and tensions at the Beltane Fire Festival. Scottish Cultural Policy Colloqium. 10 April 2013. Edinburgh: Queen Margaret University.

Matheson, C. M., Rimmer, R., \& Tinsley, R. (2014). Spiritual attitudes and visitor motivations at the Beltane Fire Festival, Edinburgh. Tourism Management, 44, 16-33. http://dx.doi.org/10.1016/ j.tourman.2014.01.023

Matthews-Salazar, P. (2006). Becoming all Indian: Gauchos, Pachamama, queens and tourists in the remaking of an Andean festival. In D. Picard \& M. Robinson (Eds.), Festivals, tourism and social change: Remaking worlds (pp. 71-83). Clevedon: Channel View.

Monga, M. (2006). Measuring motivation to volunteer for special events. Event Management, 10, 47-61.

Nurse, K. (1999). Globalisation and Trinidad carnival: Diaspora, hybridity and identity in global culture. Cultural Studies, 13, 661-690.

O'Grady, A. (2012). Spaces of play: The spatial dimensions of underground club culture and locating the subjunctive. DanceCult: Journal of Electronic Dance Music Culture, 4, 86- 106.

Partridge, C. (2006). The spiritual and the revolutionary: Alternative spirituality, British free festivals, and the emergence of rave culture. Culture and Religion, 7, 41-60. 
Philips, D. (1998). Carnival and control: The commodification of the carnivalesque at Disneyland. In N. Ravenscroft, D. Philips, \& M. Bennett (Eds.), Tourism and visitor attractions: leisure, culture and commerce (pp. 75-82). Brighton: Leisure Studies Association.

Presdee, M. (2000). Cultural criminology and the carnival of crime. London: Routledge. Quinn, B. (2003). Symbols, practices and myth-making: Cultural perspectives on the Wexford - Festival Opera. Tourism Geographies, 5, 329-349.

Quinn, B. (2005). Changing festival places: Insights from Galway. Social and Cultural Geography, $6,237-252$.

Quinn, B. (2006). Problematising 'Festival Tourism': Arts festivals and sustainable development in Ireland. Journal of Sustainable Tourism, 14, 288-306.

Ravenscroft, N., \& Gilchrist, P. (2009). Spaces of transgression: Governance, discipline and reworking the carnivalesque. Leisure Studies, 28, 35-49.

Ravenscroft, N., \& Matteucci, X. (2003). The festival as carnivalesque: Social governance and control at Pamplona's San Fermin Fiesta. Tourism, Culture and Communication, 4 (1), 1-15.

Reid, S., \& Ritchie, B. (2011). Risk management: Event managers' attitudes, beliefs, and perceived constraints. Event Management, 15, 329-341.

Richards, P., \& Ryan, C. (2004). The Aotearoa traditional Maori performing arts festival 19722000. A case study of cultural event evolution. Journal of Tourism and Cultural Change, 2, 94-117.

Ritzer, G. (2011). The McDonaldisation of society. Thousand Oaks, CA: Sage.

Rogers, N. (2002). Halloween: From Pagan ritual to party night. Oxford: Oxford University Press.

Rojek, C. (1995). Decentring leisure: Rethinking leisure theory. London: Sage.

Santino, J. (2011). The carnivalesque and the ritualesque. Journal of American Folklore, 124, 6173.

Scott, J. C. (1990). Domination and the arts of resistance: Hidden transcripts. New Haven, CT: Yale University Press.

Shields, R. (1990). The 'system of pleasure': Liminality and the carnivalesque at Brighton. Theory, Culture and Society, 7, 39-72.

Shields, R. (1991). Places on the margin: Alternative geographies of modernity. London: Routledge.

Silvers, J. R. (2007). Risk management for meetings and events. Oxford: Elsevier ButterworthHeinemann. 
Sofield, T. H. B., Mei, F., \& Li, S. (1998). Historical methodology and sustainability: An 800-yearold festival from China. Journal of Sustainable Tourism, 6, 267-292.

Sofield, T. H. B., \& Sivan, A. (2003). From cultural festival to international sport - The Hong Kong dragon boat races. Journal of Sport Tourism, 8, 9-20.

Stallybrass, P., \& White, A. (1986). The politics and poetics of transgression. London: Metheun.

Tarlow, P. W. (2002). Event risk management and safety. New York, NY: John Wiley.

Taylor, T., \& Toohey, K. (2006). Impacts of terrorism-related safety and security measures at a major event. Event Management, 9, 199-209.

Taylor, T., \& Toohey, K. (2007). Perceptions of terrorism threats at the 2004 Olympic Games: implications for sports events. Journal of Sport Tourism, 12, 99-114.

Tinsley, R., \& Matheson, C. M. (2014). Layers of passage: The ritual performance and liminal bleed of the Beltane Fire Festival, Edinburgh. In J. Laing \& W. Frost (Eds.), Rituals and Traditional Events in a Modern World (pp. 141-158). New York, NY: Routledge.

Vitos, B. (2010). DemenCZe: psychedelic madhouse in the Czech Republic. In: G. St. John (Ed.) The Local Scenes and Global Culture of Psytrance (pp. 151-169) New York, NY: Routledge.

Webb, D. (2005). Bakhtin at the seaside: Utopia, modernity and the carnivalesque. Theory, Culture and Society, 22, 121-138.

Whitford, M. (2008). Oaxaca's indigenous Guelaguetza festival: Not all that glistens is gold. Event Management, 12, 143-161.

Wiles, D. (1996). The Lewes Bonfire Festival. New Theatre Quarterly, 12, 177-191.

Xie, P. F., \& Lane, B. (2006). A life cycle model for aboriginal arts performance in tourism:

Perspectives on authenticity. Journal of Sustainable Tourism, 14, 545-561. 